УДК 504:63

(C) 2016

Писаренко П. В., доктор сільськогосподарських наук, професор, Гармаш О. I., аспірант

(науковий керівник - доктор сільськогосподарських наук, професор П. В. Писаренко)

Полтавська державна аграрна академія

\title{
ЕТНОГРАФІЧНІ ОСОБЛИВОСТІ УКРАЇНСЬКОГО НАРОДУ ТА ЇХ РОЛЬ У СТВОРЕННІ ЕКОПОСЕЛЕНЬ НА ТЕРИТОРЇ̈ УКРАЇНИ
}

\section{Рецензент - доктор сільськогосподарських наук М. Я. Шевніков}

У статті розглядаються етнографічні особливості украӥнського народу як нащадків землеробів Трипільської культури. Аналізуються основні здобутки украӥнських хліборобів ХІХ століття як представників землеробства, котре ще не зазнало згубного впливу науково-технічної револючії. Подаються відомості про "Долину Джерел», як одне з найбільших екопоселень в Україні, котре втілює у собі певні риси традииійного побуту украӥничв та здобутки науковотехнічного прогресу. Розкривається поняття Трипільська культура, екопоселення, село, садиба, хата. Та подається власне визначення поняття «екопоселення».

Ключові слова: Трипільська культура, екопоселення, село, садиба, хата.

Постановка проблеми. Вченими доведено, що проживання в сучасних містах шкодить здоров'ю людини. Це пов'язано 3 використанням залізобетону і синтетичних матеріалів, малоактивним способом життя та відсутністю контактів 3 навколишнім природним середовищем. До того ж сучасне житло не забезпечує свого основного призначення бути екологічним, чистим і корисним для життя та здоров'я людини.

Ми пропонуємо звернути увагу на втрачені національні принципи будівництва житла і ведення домашнього господарства, адже внесок трипільців у спадщину тисячоліть цілком вагомий. Найголовніше із досягнень - це закладення основ господарських систем, на базі яких існували суспільства та народи пізніших часів, включно до історичних українців.

Аналіз останніх досліджень і публікацій, в яких започатковано розв'язання проблеми. Аграрну систему трипільської культури вивчали М. Ю. Відейко, Г. О. Пашкевич, В. Хвойка, Ю. О. Шилов [7, 9]. Проблемами етнографії українського народу займалися такі дослідники: Х. Вовк, С. А. Макарчук, В. Войтович $[1,6]$ та інші вчені. Виявленню соціальної природи і сутності традицій та історії українського народного житла, його ролі і місця в суспільному житті присвячені праці В. П. Мироненко, Г. П. Євсєєва, А. О. Сардикова, М. В. Савицького [4, 8]. У Полтаві цим питанням займаються П. В. Писаренко, М. С. Самойлік. У літературі ми знаходимо мало відомостей саме про втілення етнографічних традицій у створення екопоселення.

Мета і завдання дослідження. Для створення майбутніх українських екопоселень важливе значення має досвід минулих поколінь, адже як свідчать археологічні джерела, історія українського народу налічує не одну тисячу років [2].

Наша ціль полягала в тому, щоб розглянути досягнення Трипільських землеробів, які були нашими пращурами і належали до високорозвинених культур давніх хліборобів доби неоліту та мідного віку. Вивчити основні здобутки українських хліборобів XIX століття як представників землеробства, котре ще не зазнало згубного впливу науково-технічної революції; виділити етнографічні особливості українського народу. А також подати відомості про «Долину Джерел», як одне 3 найбільших екопоселень в Україні, котре втілює у собі певні риси традиційного побуту українців.

Результати досліджень. За даними археологічних досліджень, перші поселення хліборобів з'явилися на території України у 7000 році до н.е., але найбільшого розквіту землеробство досягло саме у період Трипільської культури, яка зародилася у $5400 / 5300$ р. до н.е. і проіснувала на теренах нашої Батьківщини близько 2,5 тисяч років [7]. Трипільці володіли передовими на той час технологіями виробництва продуктів - рільництвом і тваринництвом, а також виробили оптимальну в умовах Лісостепу перелогову систему землекористування. Тому досвід їхнього господарювання можна використовувати і в сучасних екологічних поселеннях.

Ми вважаємо доцільним виділити такі етнографічні особливості українського народу:

1. Найдавнішим i найпоширенішим типом українських поселень $є$ село.

Архітектура Трипілля мала самобутній харак- 


\section{СІЛЬСЬКЕ ГОСПОДАРСТВО. ЕКОЛОГІЯ}

тер. Зазвичай поселення розташовувалось на підвищенні, аби вберегти його від затоплення і від нападів чужинців. Трипільці винайшли новий тип укріплень: домівки будували по колу, дуже щільно одне до одного таким чином, що вони утворювали собою «житлову стіну» - зовнішню стіну поселення, поєднуючи в одне ціле двоповерхові житлово-господарські комплекси. Будівлі розміщувалися паралельно одна одній на відстані 1-1,5 м і поєднувались між собою переходами на рівні другого поверху. Таке укріплення надійно захищало від ворогів. Даний тип укріплень був більш характерним для протоміст Трипілля. Зазвичай в центрі поселення розміщувалися культові споруди.

Цікава особливість трипільських поселень полягає в тому, що через кожні 50 років селище повністю спалювали і переселялися на інше місце. Цим вони запобігали виснаженню грунту та відновлювали пошкоджені землі [3].

Українське село ХІХ століття складалося 3 таких елементів:

- Сельбище - охоплює територію, на якій розташоване власне поселення - селянські двори, головна сільська дорога (вулиця), об'єкти інфраструктури.

- Центр - територія поблизу церкви або приміщення громадського самоуправління. Часто ці споруди розташовувалися біля площі та разом із нею становили центр.

- Культова споруда - церква - розташовувалася переважно в центрі села поблизу дороги або зручного проїзду. Часто біля неї було кладовище та резиденція священика.

- Виробничо-побутові об'єкти: кузня, млин, корчма, крамниця, громадська комора.

- Культурно-освітні об'єкти становили початкові школи, а також громадські організації [6].

2. Український двір включає в себе житло, господарські будівлі та прилеглий до них невеликий виробничий майданчик. Разом із садом і городом такий двір утворював садибу [6]. Садиби селян залежно від розміру наділу найчастіше мали форми видовженого прямокутника. Споруджуючи будівлі в садибі, людина віддавна намагалася відшукати й використати все найцінніше 3 навколишнього середовища. Велике значення мало орієнтування головного фасаду на південь, щоб оселя добре освітлювалася і обігрівалася. Відокремленість від житла господарських будівель, особливо призначених для утримання худоби, забезпечувала дотримання елементарних санітарно-гігієнічних норм [5]. Господарські будівлі традиційного селянського двору можна поділити на декілька груп:
- для утримання свійських тварин і птиці (хлів для великої рогатої худоби, стайня для коней, овець, саж, куча для свиней, курник для домашньої птиці);

- для зберігання продуктів сільського господарства (клуня, стодола, половник, осет, стебка, пивниця, льох, погріб, оборіг, комора, кошниця);

- для зберігання сільськогосподарського реманенту та транспортних засобів (шопа, возівня, повітка);

- окрему групу становлять малі архітектурні форми (огорожі, криниці) [6].

Ще у наших пращурів існували садиби, які складалися 3 двох-трьох житлово-господарських комплексів, поблизу житла знаходились господарчі ями, глинища і ями для зберігання припасів [3]. Поля та пасовиська розташовувалися за межами поселення. За даними А. В. Ніколової та Г. О. Пашкевич для того, аби прогодувати одну людину, потрібно було близько 1-1,5 га землі [7]. Але ці дані не враховують ні статево-вікової структури суспільства, ні додаткових джерел харчування.

3. Основним типом традиційного житла в Україні $є$ хата, яка належить за міжнародною класифікацією до так званого Вгеithausbau «широкий сільський житловий будинок» [4]. Під час будівництва враховували особливості ландшафту і клімату, хату будували 3 місцевих матеріалів, які можна було легко утилізувати. Тому будинок становив органічну єдність 3 природою i витрати на підтримку його існування були мінімальними. Історично житло не відгороджувало людину від природного оточення, а гармонійно вписувалося в ландшафт [8].

У Трипільській архітектурі, початок з якої бере наша традиційна українська архітектура, було поширене надземне житло каркасно-стовпової конструкції з дерев' яними стінами (плетеними із лози) та перекриттями, обмазаними глиною. Дах був дво- або чотирисхилим, його перекривали очеретом, оскільки солома тих злаків, які вирощували у той час, була непридатна для цього. Житло було прямокутної форми, розмірами від 4x6, 4x9 м і до 10x15, 7x33 м [3]. Площа жител була різноманітна: від $60 \mathrm{~m}^{2}$ до $300 \mathrm{~m}^{2}$. Зазвичай житло орієнтувалось на південь, південний схід. Вікна мали округлу форму. Вхід до житла знаходився із внутрішнього боку поселення. Поріг ліпили з глини, існували два типи дверей: звичайні, що обертаються, і зсувні.

Будівля трипільців була двоповерховою і являла собою житлово-господарський комплекс, перший поверх якого використовували для господарчо-побутових цілей: утримували худобу, 


\section{СІЛЬСЬКЕ ГОСПОДАРСТВО. ЕКОЛОГІЯ}

зберігали припаси, облаштовували майстерні для ремісничої діяльності, де встановлювали необхідні пристрої, зберігали сировину та реманент. Зазвичай перший поверх не опалювався. Підлога першого поверху була земляною, а другий поверх обмазували сумішшю глини 3 половою та соломою. На другому поверсі розміщувалась житлова частина, яку опалювали за допомогою відкритих вогнищ і купольних печей. Піч традиційно розташовували справа від входу. Уздовж стін розміщувались лави 3 глини, поряд 3 ними піфоси, глиняні корита 3 кам'яними зернотерками. Особливе місце займав жертовник, котрий розташовувався на відстані 1,5-2 м біля найдальшої стіни від входу. На спеціальній вимостці ставили вертикальний ткацький верстат (у період пізнього Трипілля). Житло було поділене на 2-3 камери, що відповідає кількості сімей, які проживали у цьому комплексі. Така конструкція житла давала змогу не витрачати час і місце на будівництво додаткових допоміжних споруд, а зручно їх влаштувати під одним дахом. Зустрічалися і одноповерхові житлові споруди, але це було менш поширеним явищем і відноситься до часів занепаду Трипільської культури [3].

Будівельний матеріал, 3 якого українці XIX століття зводили житлові та господарські будівлі, залежав значною мірою від місцевих природних ресурсів і від заможності конкретного селянина. Тому у північних губерніях, багатих лісом, будували 3 дерева, у Лісостепу - 3 глини, соломи й деревини, а в Степу - з глини та каменю [4].

В Україні (XIX століття) застосовували два типи конструкцій стін: зрубний (Полісся та Карпати) й каркасний (лісостепова смуга). Основою зрубних будівель є стіни з горизонтально викладених колод, брусів, з'єднаних на кутах зарубками. Стіни каркасних споруд складаються зі стовпів (стояків, сох), які закопували в землю або вставляли в нижній зрубний вінець (підвалини) [4]. На півночі Лісостепу дерев'яний каркас заповнювали деревом і глиносоломою, на півдні плетінням (лоза, очерет, глиносолома). Стіни каркасного житла обмазували 3 обох сторін глиною і білили. У степових районах поширені також житла, в яких стіни безкаркасні - зведені 3 глиносолом'яних вальків, глинолиті, 3 цеглисирівки або з природного каменю (ракушняку, солонцю) [6].

Українські будинки відрізнялися екологічністю i раціональністю об'ємно-планувальних рішень. Глина за своєю суттю $є$ цілющим матеріалом. Будинок з глини «дихає» і зберігає здоров'я мешканців. Використана під час будівництва глина регулює вологість повітря в межах 40-60\%, знижуючи таким чином кількість пилу в повітрі. Будівельних відходів у випадку використання глини не утворюється, іiі можна без шкоди для природи повернути в навколишнє середовище. Дерево $є$ природним кондиціонером, протягом доби повітря в приміщенні оновлюється двічі. Воно реагує на зміну навколишнього середовища: якщо вологість висока, дерево поглинає зайву вологу, якщо низька, воно виділяє вологу, підтримуючи постійну температуру в кімнаті. Смоли, що містяться у хвойних породах деревини, виділяють фітонциди, що дають озонуючий, оздоровчий ефект [8].

Проста селянська хата будувалася на дерев'яному каркасі. В землю закопували вертикальні стовпи 3 поздовжніми пазами, в які горизонтально вкладали різноманітні будівельні матеріали: дошки, бруски, половини колод, жердини, гілки тощо. Між ними прокладали солому, змішану 3 глиною і часто з кінським гноєм [1]. Для захисту нижніх частин будинку від вогкості, на відстані 35-40 см від стіни, весь будинок обплітали тином, висотою, як правило, не вище коліна. Порожній простір, який утворювався, заповнювали сухою піщаною землею. Отриману сходинку призьбу - обмазували жовтою глиною. Весь будинок, зовні і всередині, обмазували спочатку товстим шаром жовтої глини, змішаної з гноєм, половою і дрібною соломою. Коли перший шар висихав, мазали вдруге. Після повного висихання другого шару стіни вибілювали білою глиною або крейдою, котра i надавала хаті охайний i святковий вигляд.

Чотирьохскатний дах - стріху - укладали 3 очерету або соломи, пов'язаної акуратними снопами. Снопи робили двох видів: довші - «китиці» і короткі - «кулики». Китиці укладали по краю і кутах даху для захисту від течі. Куликами покривали дах по всіх схилах. Іноді дах покривали просто намолоченою соломою, при цьому використовували лише житню солому, завдяки іiі міцності і стійкості до гниття. На зиму стіни обставляли солом'яними снопами для захисту від холоду [8].

Що стосується конструкції стелі, то посередині, упоперек будинку укладали велику балку сволок. Сволок і краї стін служили опорою для горизонтальних колод і стелі. Сволок був необхідний у зв'язку з давньою традицією присипки стелі хати товстим шаром піску, що сприяло утепленню житла. Цю важливу конструктивну деталь хати українці, прикрашали різьбою, розписом [6].

Підлога (долівка) у житлі найчастіше була глиняною. 3 другої половини XIX ст. заможні 


\section{СІЛЬСЬКЕ ГОСПОДАРСТВО. ЕКОЛОГІЯ}

верстви селянства клали дерев'яну підлогу. Іноді вона була комбінованою: біля печі - глиняна, а на решті житлової площі - дерев'яна. Вікна хати прикрашали віконницями, пофарбованими в синій або зелений колір. Зазвичай стіни білили тричі на рік: до Трійці, до Покрови і перед настанням зимових морозів [8].

Приблизно 3 середини XIX ст. найпоширенішим типом планування традиційного житла українців стало трикамерне, типу: хата - сіни комора. При вході до будинку - сіни, у яких розташовувався і вхід на горище. В українців сіни $є$ холодним неопалюваним приміщенням. Праворуч сіней - комора, - де зберігалися різні продукти харчування, посуд. Інколи замість комори створювали хатину - жиле приміщення меншого розміру. В цьому випадку продукти зберігалися прямо в сінях. Хатина, як правило, має природне освітлення і пов'язується безпосередньо з основною жилою кімнатою. В кінці XIX ст. планування типу «хата i хатина» було поширене в центральних і східних районах лісостепової частини України, особливо на Полтавщині. Зліва від сіней, за дверима з високим порогом, розташовувалася житлова частина будинку.

Найважливішим елементом інтер'єру житлового приміщення українців був опалювальний пристрій - вариста піч. Українська піч, так само як і трипільська, розташовувалася в передньому куті хати справа від дверей біля напільної та сінешньої стін. Вона ефективно обігрівала житлове приміщення і відкривала широкі можливості для термічної обробки їжі - печіння, варіння, тушкування, сушіння. Крім того, на печі спали діти та найстарші члени сім'ї. Піч займала приблизно четверту частину житлового приміщення. Іїі устя було повернуте до фасадної, чільної стіни. По діагоналі від печі в хаті влаштовували «покуть», «божий кут», (покуть розміщувалася аналогічно жертовнику трипільців) на стінах якого вішали ікони, прикрашені рушниками. Під образами вздовж чільної та причілкової стін традиційно розміщувалися широкі лави. Простір між піччю і причілковою стіною займав «піл». Ліворуч від дверей в кутку розташовувалася полиця для посуду («мисник», «судень») [8].

4) Споконвіків український народ займався землеробством. Цьому сприяли ландшафтнокліматичні умови: родючий грунт, помірна температура, рівнинна або слабо горбиста місцевість у більшості регіонів. Вигідні умови для вирощування збіжжя стали однією $з$ причин ранньої появи стаціонарних поселень, а це, у свою чергу, сприяло створенню своєрідної аграрної народно-традиційної культури, в основі якої за- кладено цілий спектр обрядів, звичаїв, ритуалів, магічних дій, найтісніше пов'язаних 3 хліборобською діяльністю [5].

Серед різних видів сільськогосподарських занять, якими українці займалися в минулому i займаються досі, на особливу увагу заслуговують головні - землеробство і скотарство. Землеробство поділяється на три окремі галузі: рільництво, городництво і садівництво.

Трипільці розробили оптимальну в умовах Лісостепу перелогову систему землекористування. Рільництво мало мотичний характер обробітку грунту. За свідченням С. М. Бібікова, існують непрямі докази того, що трипільське хліборобство було орним. Наявність значних природних ресурсів - угідь - дала змогу переносити поля (а разом $з$ ними і поселення) на родючі грунти приблизно кожні 50-70 років.

Основними культурами були пшениця, ячмінь, горох, вика. Пізніше почали вирощувати просо, овес, жито, коноплі і льон. Трипільці віддавали перевагу плівчастим пшеницям та ячменю, які були добре пристосованими як до фізикогеографічних умов, так і до примітивного рівня хліборобства. Потрібно зазначити, що нині посилено культивують полбу - древню плівчасту пшеницю, яку вважають джерелом «екологічної їжі» [7].

Традиційно система використання та обробітку грунту хліборобів ХІХ ст. базувалася на таких трьох елементах: відпочинок експлуатованої земельної ділянки, методи обробітку грунту і певна почерговість висіву культур. Віддавна на українських етнічних землях вирощували різні злакові (пшеницю, жито, ячмінь, просо, овес, гречку та ін.), зернобобові (біб, горох, сочевицю тощо) і технічні (коноплі, льон, рижій) культури.

Повсюдно дотримувалися чотириетапної сезонної оранки: весняна оранка під ярові культури, оранка чорного пару, літня оранка толоки й обробіток стерні під озимі культури, нарешті зяблева оранка. Наші предки застосовували ефективні організаційні й технологічні засоби для запобігання втрати родючості. Одним 3 них була система рільництва, серед якої агрономічною ефективністю вирізнялося Трипілля. Проводилося систематичне удобрення грунту i ефективно використовувалися органічні та мінеральні добрива [6].

Українці, як один з найдавніших у Свропі хліборобських етносів, розпушували грунт за допомогою цілого арсеналу орних (рала, сохи, плуга) i ручних (мотик, сап, заступів) знарядь праці. Археологічні знахідки аграрних пам'яток вказують, що в етнічних межах України хлібороби 


\section{СІЛЬСЬКЕ ГОСПОДАРСТВО. ЕКОЛОГІЯ}

користувалися знаряддями, які за технікоконструктивною характеристикою були на рівні тих, що побутували в інших європейських регіонах того часу. Це свідчить про досить високий рівень хліборобської культури нашого народу [6].

Після оранки скиби розпушували різними методами і різними приладами: «ралили» ралом, скородили «драпаком» («грапою») або бороною впоперек і повздовж. Якщо було багато робочої худоби, то боронували землю одночасно з оранкою. Розпушивши грунт, хлібороб відразу приступав до сівби. На більшості території України засіяні ниви обов'язково заволочували боронами. Значну увагу українські селяни приділяли догляду за посівами, бур'яни скошували чи проривали руками. Для захисту від птахів влаштовували по межах та посеред ниви опудала.

У жнива працювали всі дорослі члени родини. Косили лише чоловіки, серпами жали жінки. Для обмолоту використовували ціп, застосовували різні котки чи ганяли худобу по розстеленим снопам [1].

Городництво відоме в Україні з глибокої давнини. До початку XX ст. воно мало переважно присадибний характер. Згідно 3 народною традицією селяни розділяли свої городи на три умовні частини: на «плеса», «грядки» i «капусники». Плесо в городі - це широка довгаста ділянка, грядка - вузька, довга і висока ділянка, капусник - найнижче і найвологіше місце в городі. Вирощували таку городину: картоплю (з 1764 р.), буряки, капусту, цибулю і часник, квасолю, огірки. На території Південної України і Середнього Подніпров'я було розвинуте баштанництво. В другій половині ХІХ ст. місцеве населення почало розводити також помідори (1780 р.). Повсюдно на українській етнічній території в невеликій кількості сіяли мак, кріп, моркву, редьку, петрушку й інші городні культури [5].

Садок - це одна 3 найхарактерніших рис українського двору. В Україні широко культивували: яблуні, груші, сливи, вишні. Виноград, абрикоси, персики, шовковицю, волоський горіх вирощували переважно на Півдні України. Майже повсюдно у селянській садибі розводили різні кущі: малину, агрус, смородину.

5) Характерна особливість господарського життя українського селянства полягала у тісному взаємозв'язку хліборобства 3 тваринництвом. Основну увагу українські селяни приділяли насамперед розведенню великої рогатої худоби, яка забезпечувала їх молочними продуктами, шкірою та м'ясом. Протягом віків основною тягловою силою у господарстві були воли, з ХІХ ст. вола як робочу худобу поступово витіснив кінь.
Вівчарство у господарстві виконувало допоміжну роль, забезпечуючи населення вовною та хутром. У багатьох регіонах України розводили кіз, а відгодівля свиней задовольняла потреби населення в салі та м'ясі. У кожному селянському дворі обов'язково розводили курей, гусей, качок, індиків та іншу птицю [5].

Згідно 3 визначенням із Глобальної мережі екопоселень (GEN), екологічне поселення (екопоселення) - це альтернативне або традиційне поселення, створене для регіональної інтеграції екологічного, економічного, соціального та культурного аспектів сталого розвитку з метою відновлення соціального і природнього середовища [10]. Ми вважаємо, що до цього визначення потрібно додати етнографічну складову.

Екологічне поселення (екопоселення) - це альтернативне або традиційне поселення, створене для регіональної інтеграції екологічного, економічного, соціального та культурного аспектів сталого розвитку з метою відновлення соціального i природнього середовища і відповідає етнічним особливостям та традиціям того народу, який мешкає на даній території.

На сьогодні в Україні не існує такого екопоселення, яке повністю могло б відповідати принципам сталого розвитку і бути самодостатнім. Однак спроби створення такого екопоселення ведуться.

«Долина Джерел» - найбільше екопоселення України, де мешкають 15 сімей - близько 70 чоловік і розташовано 56 ділянок під родові поселення. Воно засноване у 2003 році в околицях с. Мотижин, Київської області. Поштовхом до створення поселення стали ідеї, викладені в книгах Володимира Мегре 3 серії «Дзвінкі кедри Росії». Вся земля (86 га) розділена на ділянки i знаходиться в приватній власності. Виділено 56 ділянок під облаштування родових помість, дев'ять гектарів землі в центрі поселення призначені для загального користування. У поселенні проведено електрику, прокладені грунтові дороги, облаштовано понад 20 озер.

Спосіб життя жителів «Долини Джерел» повністю відповідає принципам організації екопоселень (за ЦИРКОН):

1. Жителі займаються органічним землеробством і відмовились застосовувати отрутохімікати і пестициди на території поселення;

2. Жителі «Долини Джерел» вирощують органічні продукти харчування, виробляють молочні продукти, трав'яні чаї, виготовляють одяг з вовни, обереги, сувеніри, натуральну косметику;

3. Відмовилися від використання побутової хімії; 


\section{СІЛЬСЬКЕ ГОСПОДАРСТВО. ЕКОЛОГІЯ}

4. За п'ятнадцять років існування поселення нагромаджено значний досвід 3 екологічного будівництва - будують енергоефективні будинки 3 місцевих матеріалів (зокрема 3 глини, соломи, дерева), використовуються відновлювальні джерела енергіi;

5. Сусіди охоче діляться один 3 одним і 3 жителями інших поселень саджанцями, підтримують один одного в будівництві та облаштуванні помість, беруть участь у спільних екологічних акціях зі збору та утилізації сміття на територіях, прилеглих до поселення.

6. Здоровий спосіб життя i заняття спортом мають особливе значення для багатьох жителів «Долини Джерел».

7. Регулярно діють різноманітні майстерні 3 народних ремесел. Проводяться заняття 3 вишивання, писанкарства, виготовлення оберегів із соломки.

8. У поселенні діє заборона на паління, вживання алкоголю та використання ненормативної лексики [11].

Висновок. Отже, екопоселення - це поселення людей, які прагнуть створити модель стійкого (збалансованого) життя. Кожній країні притаманні екопоселення, які за своєю специфікою відповідають національним особливостям народу цієї країни.

У своїй статті ми розглянули досягнення Трипільських землеробів і проаналізували основні

\section{БІБЛІОГРАФІЯ}

1. Вовк $X$. Студії з української етнографії та антропології / Х. Вовк. - К. : Мистецтво, 1995. $382 \mathrm{c}$.

2. Грушевський М. Історія України-Руси: в 11 т., 12 кн. / М. Грушевський. - К. : «Наукова думка», 1991. - Т. І. До початку ХІ ст. [Електронний pecypc]. - Режим доступу : http://litopys.org.ua/ hrushrus/iur1.htm.

3. Енциклопедія трипільської цивілізації / гол. ред. Л. М. Новохатько. - К. : Укрполіграфмедіа, 2004. - Т. 1. -703 c.

4. Свсєєва Г. П. Традиції українського народу у формуванні архітектури житлової забудови екопоселень / Г. П. Євсєєва // Вісник ПДАБА. 2013. - №10. - С. 64-68.

5. Історія української культури. Том 2 (Українська культура XIII - першої половини XVII століть). - К., 2001 [Електронний ресурс]. - Режим доступу : http://litopys.org.ua/istkult2 /ikult2.htm.

6. Макарчук C.A. Етнографія України С. А. Макарчук. - Львів : «Світ», 2004. - 520 с.

7. Пашкевич Г. О., Відейко М. Ю. Рільництво здобутки українських хліборобів XIX століття як представників землеробства, котре ще не зазнало згубного впливу науково-технічної революції. Це дало змогу нам виділити такі етнографічні особливості українського народу:

1) Село - це найпоширеніший тип українських поселень.

Українська садиба складається 3 житла, саду і огороду.

Хата є основним типом традиційного житла в Україні.

Споконвіків український народ займається землеробством і тваринництвом.

У нашій концепції створення екологічних поселень на території України ключове місце займає ідея українського села як прообразу сучасного українського екологічного поселення, яке об'єднає у собі всі досягнення наших пращурів та здобутки науково-технічної революції.

«Долина Джерел» - українське екопоселення, яке поєднує в собі певні риси традиційного побуту українців і здобутки науково-технічної революції.

Перспективи подальшої роботи в цьому напрямі. Робота по цьому питанню буде продовжена. Розробляються концепція створення екопоселень на території України. Планується відвідати більшість українських екопоселень для оцінки їх стану розвитку і створити єдиний реєстр екопоселень України.

племен трипільської культури / Г. О. Пашкевич, М. Ю. Відейко. - К., 2006. - 145 с.

8. Сардыкова А. О. Исторические предпосылки формирования энергоэффективного жилья / А. О. Сардыкова, В. П. Мироненко // Вісник ПДАБА. - 2010. - №12. - С. 43-50.

9. Шилов Ю. А., Моргун Ф. Т. Пирамиды степей и ноосфера / Ю. А. Шилов, Ф. Т. Моргун // Вернадсікіанська ноосферна революція у розвязанні екологічних та гуманітарних проблем // Збірник матеріалів IV Всеукраїнських Моргунівських читань із міжнародною участю, присвячених 90-річчю від дня народження видатного українця. - Полтава : Дивосвіт, 2014. - С. 22-36.

10. Сайт глобальной сети экопоселений Global Ecovillage Network (GEN) [Електронний pecypc]. - Режим доступу : http:/gen.ecovillage.org.

11. Сайт поселення родових помість «Долина Джерел» [Електронний ресурс]. - Режим доступу : http://dolyna.kiev.ua/about. 